\title{
Tolerance of some wood-decomposing basidiomycetes to aromatic compounds related to lignin degradation
}

\author{
VeikkoHintikka
}

Finnish Forest Research Institute, Unioninkatu 40 A, Helsinki 17, Finland

\begin{abstract}
The tolerance of 46 wood-decomposing Hymenomycetes to 23 phenolic and related aromatic compounds was investigated by adding the compoudns to Hagem agar after autoclaving and cooling it to $70-80^{\circ} \mathrm{C}$, and measuring the radial growth on these substrates after 8-10 days (Table 1). Considerable differences in tolerance were found between the species. The most tolerant were brown-rot fungi, white-rot fungi being on the average more sensitive. When natural substrates of these fungi were treated with $\mathrm{FeCl}$, solution to reveal the presence of phenols, a positive reaction was generally obtained with the brown-rot, but not with the white-rot fungi. The results suggest that phenolic compounds may be important in the ecology of wood-decomposing fungi, e.g. in connection with the drying of wood.
\end{abstract}

\section{Introduction}

Considerable attention has been paid in recent years to the roles played by phenolic compounds in the degradation of lignin, hostparasite interactions and as constituents of higher plants (PrIDHAM 1960, HARborne 1964, Kursanov \& Zaprometov 1968). In trees, phenolic compounds may have several different origins: i) they may occur as normal constituents of living wood and bark, either free or as glycosides; ii) they may be produced by the tree as a reaction to invading pathogens (SHAIN 1967); iii) they may accumulate as lignin degradation products owing to the activity of fungi; or iv) they may be synthetized by fungi or other wood-inhab- iting micro-organisms (Power et al. 1965, Armand \& Thivend 1965).

Wood decay in living and dead wood is generally caused a number of basidiomycetes, many of which are effective lignin decomposers. Many earlier investigations (e.g. ReNNerfelt \& NAGHT 1955, GADD 1957) have indicated that phenolic compounds exert a toxic influence on the growth of these fungi. This paper attempts, by studying the tolerance of some common wood-decomposing basidiomycetes to phenolic compounds known to occur in nature, to obtain preliminary information on the possible effects of these compounds in fungal ecology.

\section{Methods}

Fungus strains preserved in the Forest Biology Laboratory, Finnish Forest Research Institute, were used. The strains were kept on Hagem agar ( $5 \mathrm{~g}$ glucose, $5 \mathrm{~g}$ malt extract, $0,5 \mathrm{~g} \mathrm{KH}_{2} \mathrm{PO}_{4}, 0.5 \mathrm{~g} \mathrm{NH} \mathrm{Nal}_{4} 0.5 \mathrm{~g} \mathrm{Mg}$
$\mathrm{SO}_{4}, 0.5 \mathrm{ml} \mathrm{FeCl} 31 \%$ solution, $15 \mathrm{~g}$ agar, $1000 \mathrm{ml}$ dist. $\mathrm{H}_{2} \mathrm{O}$ ) at $+5^{\circ} \mathrm{C}$ with approximately two transfers a year. Most of the strains were isolated in the years 1966-68.

The following compounds were used: ani- 
sic acid Fluka puriss., benzaldehyde reag. qual., benzoic acid $\mathrm{BDH}$ anal. reag., caffeic acid Fluka pur., cinnamic acid Merck, pcresol Fluka puriss., 2,5-dihydroxybenzoic acid Fluka puriss., ferulic acid Fluka purum, gallic acid, 4-hydroxybenzoic acid Fluka puriss., 4-hydroxybenzaldehyde Koch-Light, pure, guaiacol Rhone Poulenc, 3-methoxybenzoic acid Fluka purum, phenol BDH anal. reag., protocatechuic acid Sigma, pyrocatechol Merck pro anal., pyrogallol Merck pro anal., resorcinol BDH anal. reag., salicylic acid BDH anal. reag., syringic acid Fluka purum, tannic acid Baker analyzed reag., 3,4, 5-trimethoxybenzoic acid Fluka purum, vanillic acid Fluka purum, thymol tech., vanillin $\mathrm{BDH}$ anal. reag., veratric acid Fluka puriss.

The tolerance was studied on Hagem agar, to which weighed amounts of phenolics were added after it had been autoclaved and cooled to $80-70^{\circ} \mathrm{C}$, and which was poured into $10 \mathrm{~cm}$ petri dishes. Although the phenols were not sterilized, infection by molds and bacteria proved to be negligible. Radial growth on the agar was measured after 6-10 days. The results are given in Table 1.

\section{Results}

If we suppose that a natural wood substrate contains certain phenolic compounds, we can see from Table 1 that the activity and rapidity of growth of the wood-decomposing basidiomycetes investigated will differ in many respects from that observed on standard media. The species listed below ar those shown by their radial growth to be the most active at high concentrations of the respective compounds.

Anisic acid: Laetiporus suphureus, Gloeophyllum sepiarium, Lentinus lepideus, $\mathrm{Pa}$ nellus serotinus, Fomitopsis annosa, Pleurotus ostreatus.

Benzoic acid: Gymnopilus penetrans, Stereum sanguinolentum; tolerance of other species fairly uniform.

Caffeic acid: Fomitopsis pinicola, Laetiporus sulphureus, Daedalea quercina, Piptoporus betulinus, Inonotus rheades.

Cinnamic acid: Stereum purpureum, Coriolus hirsutus, Panellus serotinus, Phellinus pini, Pholiota alnicola.

p-cresol: Inonotus rheades, Lentinus lepideus, Stereum purpureum, Polyporus brumalis, Phellinus pini, Fomitopsis pinicola.

2,5-dihydroxybenzoic acid: Daedalea quercina, Fomitopsis pinicola, Laetiporus sulphureus, Coriolus vaporarius, Coriolellus serialis, Inonotus rheades.

Ferulic acid: Stereum sanguinolentum, Coriolus hirsutus, Hirschioporus abietinus, Phel-linus pini, Pycnoporus cinnabarinus, Pleurotus ostreatus, Gloeophyllum sepiarium.

Gallic acid:Fomitopsis pinicola, Daedalea quercina, Inonotus rheades, Laetiporus sulp- hureus, Piptoporus betulinus, Coriolellus serialis.

Guaiacol: Inonotus rheades, Lentinus lepideus, Phellinus pini.

4-Hydroxybenzaldehyde: Gloeophyllum sepiarium, Phellinus pini, Xeromphalina campanella, Stereum sanguinolentum, Phellinus tremulae, Psathyrella spadicea.

3-Methoxybenzoic acid: Gymnopilus penetrans, Phellinus tremulae, Stereum purpureum, Polyporus brumalis, Coriolus zonatus, Pholiota aurivella.

Phenol: Gloeophyllum sepiarium, Fomitopsis pinicola, Phellinus pini, P. tremulae, Stereum purpureum, Coriolus hirsutus.

Protocatechuic acid: did not inhibit the growth rate of most species. Inhibition distinct in Pycnoporus cinnabarinus, Pleurotus ostreatus, and in Flammulina velutipes.

Pyrocatechol: Phellinus pini, Daedalea quercina, Stereum purpureum, Polyporus brumalis, Fomitopsis pinicola.

Pyrogallol: Polyporus brumalis, Stereum sanguinolentum, Gloeoporus dichrous, Lentinellus omphalodes, Kuehneromyces mutabilis, Fomes fomentarius.

Resorcinol: Coriolus hirsutus, Daedalea quercina, Coriolus zonatus, Inonotus rheades, Panellus serotinus, Polypilus frondosus, Fomitopsis pinicola.

Salicylic acid: Gloeophyllum sepiarium, Laetiporus suphureus, Lentinus lepideus, Daedalea quercina, Polypilus frondosus, $\mathrm{Pa}$ nellus serotinus.

Syringic acid: Laetiporus sulphureus, Fomitopsis pinicola, Coriolus vaporarius, Pipto- 
CONCENTRATION $\%$

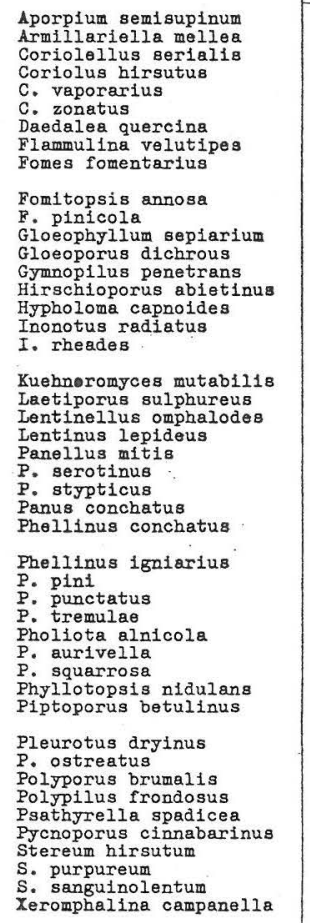

pH

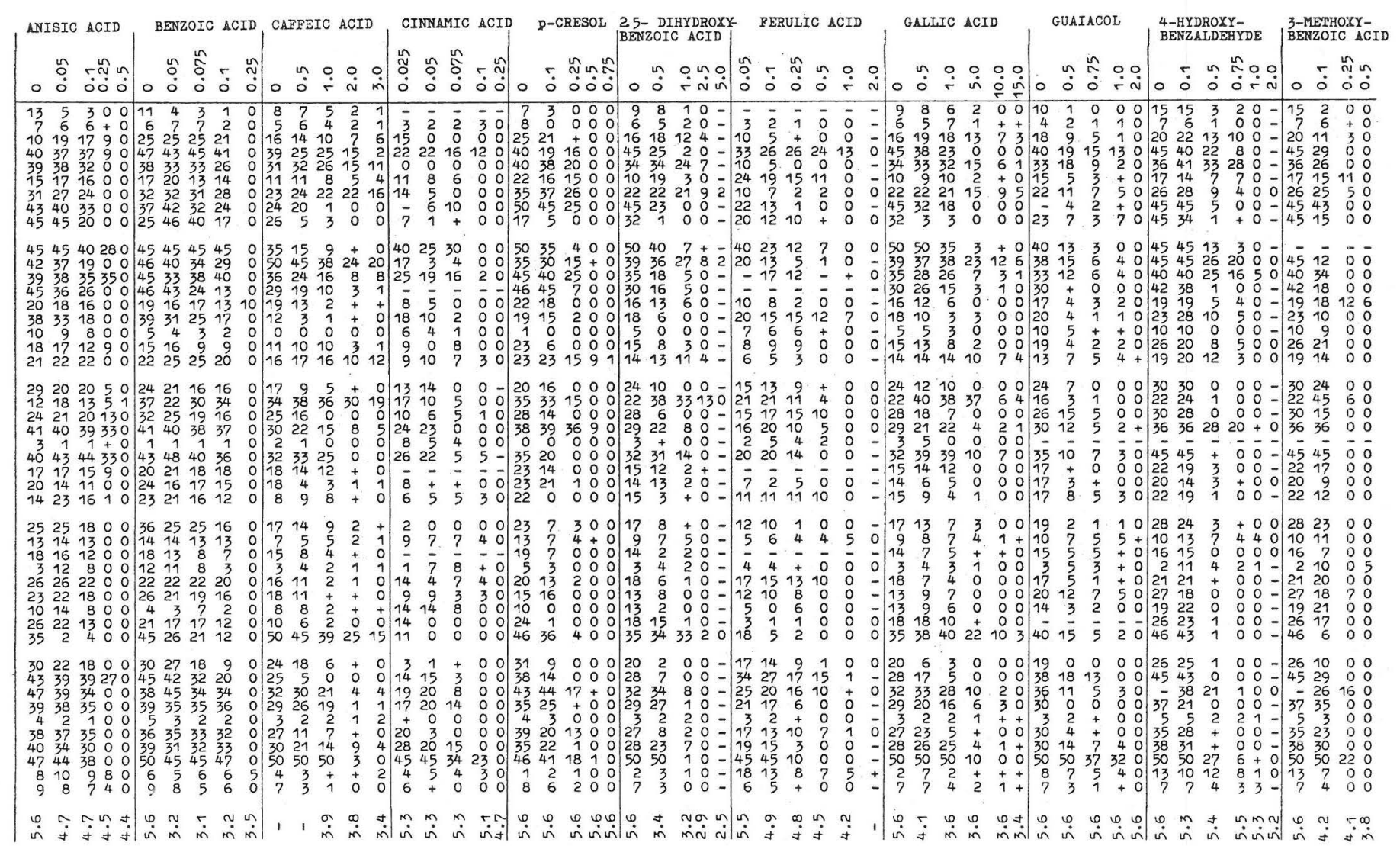

Table 1. Radial growth of certain wood-decomposing fungi at different concentrations ( $\% 0$ ) of phenolic compounds. The nomenclature follows BONDARTSEV (1953) and MOSER (1967). 


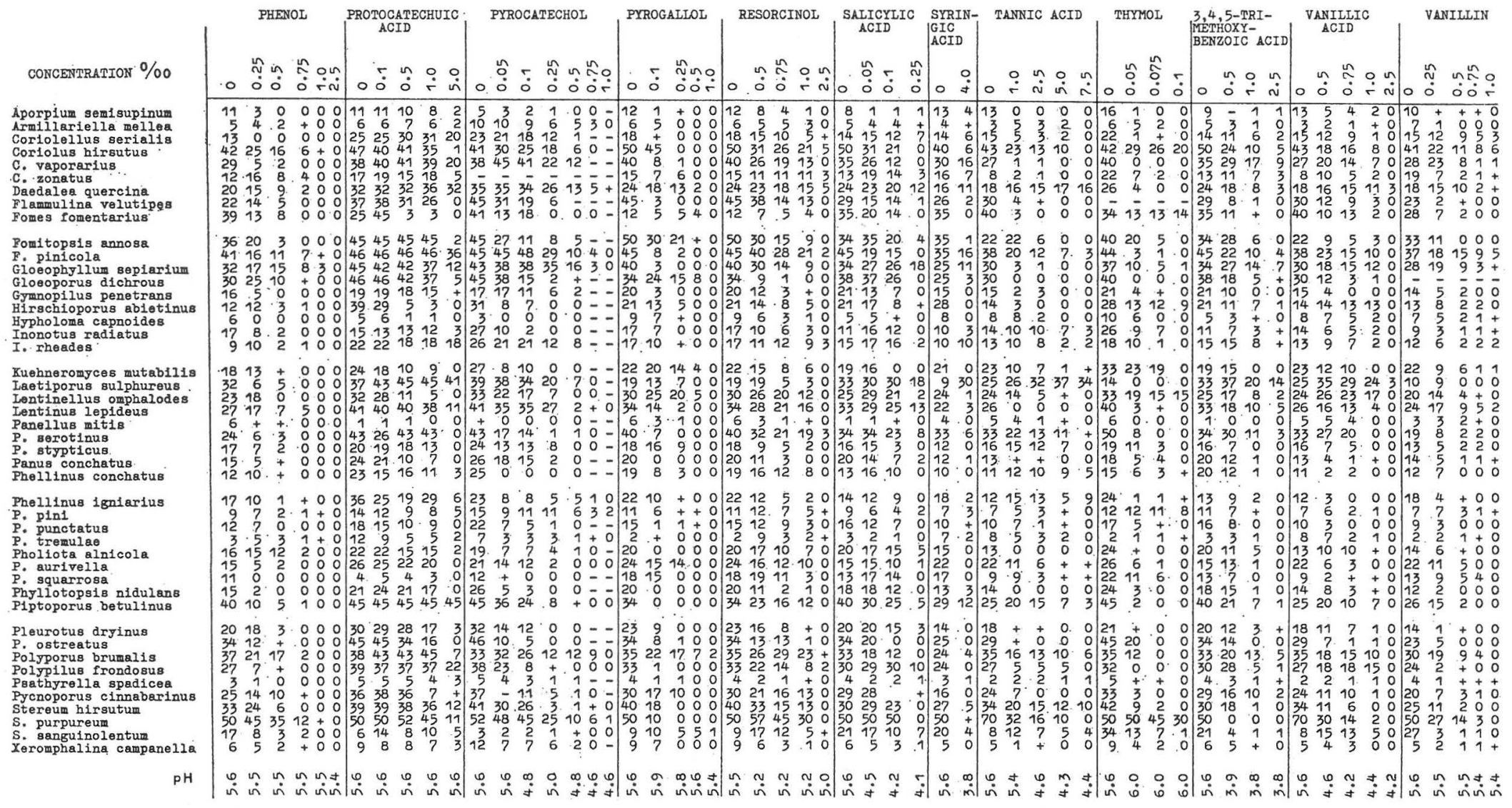

Table 1 (continued). Radial growth of certain wood-decomposing fungi at different concentrations (\%) of phenolic compounds. 
porus betulinus, Gloeophyllum sepiarium, Daedalea quercina.

Tannic acid: Laetiporus sulphureus and Daedalea quercina grew well in $0.75 \%$ solution, Stereum hirsutum and Phellinus igniarius significantly less well.

Trimethoxybenzoic acid: Laetiporus sulphureus, Coriolus vaporarius, Gloeophyllum sepiarium, Coriolus hirsutus, Lentinus lepideus, Polyporus brumalis.
Thymol: Stereum purpureum, Coriolus hirsutus, Lentinellus omphalodes, Fomes fomentarius, Hirschioporus abietinus.

Vanillic acid: Laetiporus sulphureus, Daedalea quercina, Lentinellus omphalodes, Polypitus frondosus, Hirschioporus abictinus, Gloeophyllum separium.

Vanillin: Coriolus hirsutus, Fomitopsis pinicola, Coriolellus serialis, Inonotus rheades, Lentinus lepideus.

\section{Discussion}

The toxicity of phenols is in many cases highly dependent on environmental conditions, especially on pH (Cochrane 1958, Cruigkshank \& Perrin 1964). As seen from Table 1, the acidity of the medium was in several cases considerably increased when the phenolic compounds were added. The acidity of wood attacked by wood-rotting fungi varies within fairly wide limits, $\mathrm{pH}$ values from 2.8 to 4.0 being common, and for this reason strongly buttered media were not used. In addition, the reaction of the fungus to phenolic compounds can be modified by altering the composition of the medium in regard to its nitrogenous compounds, especially amino acids (F LOOD \& Kirkham 1960). Also the age of the isolated culture seems to some extent to influence the results, especially in pathogenic species.

Among the species investigated, it is possible to distinguish a group of species which have in general a high tolerance to the compounds studied, viz.: Fomotopsis pinicola, Lentinus lepideus, Daedalea quercina, Laetiporus sulphureus, Stereum sanguinolentum, Gloeophyllum sepiarium, and Phellinus pini. Of these fungi, Lentinus is known to be fairly resistant to phenolic compounds used in wood protection, and Phellinus pini grows in nature in pine heartwood, the fungitoxicity of which depends largely on its content of pinosylvin. Except for Stereum and Phellinus, the species mentioned are pronounced brown-rot fungi (Cartwright \& Findlay 1958, K̈̈̈̈RIK 1965).

According to Cserjesi (1969), brown-rot fungi are more tolerant to dihydroquercetin, which occurs in bark of Pseudotsuga and $L a-$ rix, than white-rot fungi.

In connection with the present investiga- tion, observations on the occurrence of phenolic compounds in nature were made by applying a solution of $1 \% \mathrm{FeCl}_{3}$ in $5 \%$ ethanol to wood near the basidiocarps of $\mathrm{ca}$. 30 wood-rotting fungi. This reagent reacts with orto-diphenols producing a blackish color. Sound wood does not react except near the cambium. The natural substrates of the following species gave a strong reaction with $\mathrm{FeCl}_{3}$ : Fomitopsis pinicola, Gloeophyllum sepiarium, Piptoporus betulinus, Daedalea quercina, and Laetiporus sulphureus. When these species and Fomitopsis annosa were grown aseptically on pieces of birch wood for 3 months, a positive reaction with $\mathrm{FeCl}_{3}$ was obtained, but not with 14 white-rot fungi. Thus there seems to exist a certain correlation between the tolerance of brown-rot fungi to phenolic compounds and the occurrence of ferric-chloride positive substances in wood decomposed by the fungi in question.

It is interesting to note that certain species which are in most cases highly tolerant to most of the compounds investigated are in some cases rather sensitive. For instance, cinnamic acid inhibited the growth of Lentinus lepideus more than that of other brown-rot fungi. Caffeic acid, which is known from pine bark (Oksanen 1961), and pyrocatechol proved to be slightly more toxic to Fomitopsis annosa than to other rapidly growing species, and this was also the case with salicylic acid and Pleurotus ostreatus and Kuehneromyces mutabilis. Among species which often grow together in birch trunks, Fomitopsis pinicola is in general most tolerant to most compounds, but at high concentrations of pyrogallol Fomes fomentarius, Gloeoporus dichrous, Lentinellus omphalodes, and Kuehneromyces mutabilis seem to be more active 


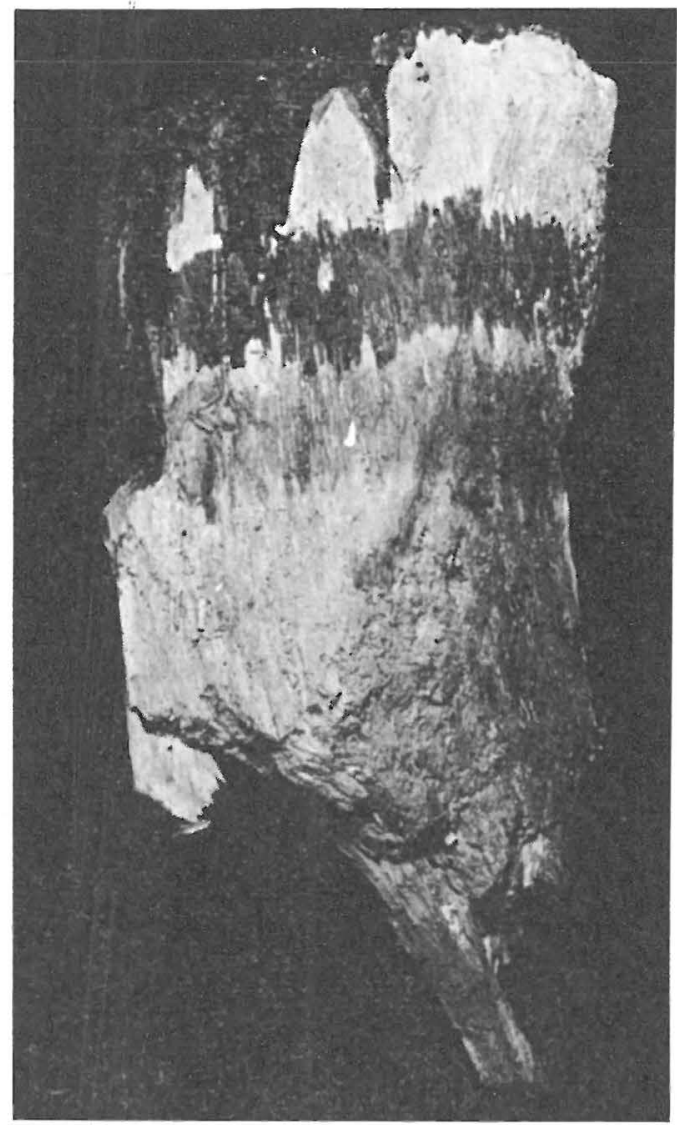

Fig. 1. A piece of spruce stump decomposed by Fomitopsis pinicola, treated with $\mathrm{FeCl}_{3}$ (above) and diazotized sulfanilic acid (below) to reveal phenolic compounds.

than $F$. pinicola. According to Siegle (1967), pyrogallol occurs as a glycoside in the heartwood of Betula papyrifera. In the present material remarkably many of the species most active in pyrogallol medium occur in nature in birch wood.

Our information concerning the occurrence and absence of the investigated compounds in natural wood and in wood decomposed by micro-organisms is not comprehensive enough to allow comparisons between the tolerances of decomposing species and the substrate in all cases. Oak wood is, however, known to contain considerable amounts of tannic acid (KARRER 1958) and the species of the present material most tolerant to this compound, Laetiporus sulphureus and Daedalea quercina, occur commonly in oak wood.
Ferulic acid occurs, according to ERDTMAN (1958) in healing wounds of Pinus, and among the species having the highest tolerance to it were Stereum sanguinolentum and Phellinus pini, which occur as wound parasites of Pinus, and Hirschioporus abietinus, which is one of the first colonizers of fallen spruce. On the other hand, Robisss \& HerVEY (1965) have found that this acid stimulates the growth of certain wood-destroying fungus species, which are not included in this investigation.

Lignin from the wood of deciduous trees is known to yield more syringyl groups than lignin from conifer wood. In the present experiments, syringic acid and syringaldehyde were not significantly more favorable to the growth of species occurring in nature in deciduous wood than to that of species found in conifer wood.

In general, species which are more or less primary wood decomposers in nature, were by and large the most resistant to the phenols, and species occurring in wood at a more advanced stage of decay were more sensitive, e.g. Xeromphalina campanella, but there were many exceptions.

Among fungi growing in aspen wood Inonotus rheades was especially resistant to phenols, e.g. to p-cresol, to which it was more tolerant than Lentinus lepideus.

When wood dries, its moisture content decreases from $150 \%$ to ca. $30 \%$, and the concentration of the solutions in the wood should consequently increase at least 5-fold, near the surface possibly even more owing to the transpiration stream. It is interesting to note that some of the most resistant species often grow in wood exposed to drying, as Gloeophyllum sepiarium, Coriolus vaporarius, and Lentinus lepideus.

On the basis of tolerance alone, it is not possible to assess exactly the role of the compounds investigated in the ecology of wooddecomposing fungi, as in the changing conditions in natural wood account must be taken of the ability to utilize and detoxify these compounds (LyR 1962) as well as of the possible adaptation of mycelia to these compounds. In certain cases, the metabolic products may be more toxic than the original compound (CserJesi 1969). In addition, many mold species are known to utilize these compounds in nature (HENDERson 1965, JoNES and FARMER 1967). 


\section{Acknowledgements}

This investigation has been carried out in the Finnish Forest Research Institute on a grant from Finnish State Board of Agri- culture and Forestry. The author is indebted to Miss Ritva KLemetri for technical assistance.

\section{REFERENCE}

Armand, D. \& S. Thivend, 1965: Sur la production d'acides phénols par des mycéliums d'Hyménomycétes lignicoles en millieu glucosé. - Rev. Myc. 30, 215-224.

Bondartsev, A. S., 1953: Trutovye griby evropeiskoi chasti SSSR i Kavkaza. - Moskva. $1.106 \mathrm{pp}$.

Cartwright, K. S. G. \& W. P. K. Findlay, 1958: Decay in timber and its prevention. London. 332 pp.

Cochrane, V. W., 1958: Physiology of fungi. New York. 524 pp.

Gruickshank, I. A. M. \& D. R. Perrin, 1964: Pathological function of phenolic compounds in plants. - J. B. HARBorne, ed, Biochemistry of phenolic compounds 512 544. London and New York.

Cserjesi, A. J., 1969: Toxicity and biodegradation of dihydroqercetin. - Can. J. Microbiol. 15, 1137-1140.

ERdtman, H., 1958: Kärnved och kärnvedskemi. - Svensk Papperstidning 6.1, 625-632.

Flood, A. E. \& D. S. Kirkham, 1960: The effect of some phenolic compounds on the growth and sporulation of two Venturia species. - Phenolics in plants in health and disease, ed, by. J. B. Pridham, 81-84. Oxford.

GADD, O., 19:57: Wood decay resulting from rot fungi. - Paper and Timber 39, 363-374.

Harborne, J. B. ed., 1964: Biochemistry of phenolic compounds. - London and New York. 618 pp.

Henderson, M. E. K., 1965: Enrichment in soil of fungi which utilize aromatic compounds. - Plant and Soil 23, 339-350.

Jones, D. \& V. C. FARMer, 1967: The ecology and physiology of soil fungi involved in the degradation of lignin and related aromatic compounds. - Journ. Soil Sci. 18, $74-84$.
KARRER, W., 1958: Konstitution und Vorkommen der organischen Pflanzenstoffe (exclusive Allkaloide). - Basel und Stuttgart. $1207 \mathrm{pp}$.

Kursanov, A. L. \& M. N. Zaprometov, editors, 1968: Fenolnyie soedineniya i ih biologitseskie funktsii. - Moskva. 421 pp.

KäÄrK, A., 1965: The identification of mycelia of wood-decay fungi by their oxidation reactions with phenolic compounds. - Studia Forestalia Suecica 26. 20 pp.

LYR, H., 1962: Detoxification of heartwood toxins and chlorophenols by higher fungi. - Nature 195, 289-290.

Moser, M., 1967: Die Röhrlinge und Blätterpilze (Agaricales). - Kleine Kryptogamenflora von Deutsichland, herausig. von H. GAMS, Band II b/2. Jena. 443 pp.

Oksanen, H., 1961: Paper chromatography of phenolic constituents of the bark of pine (Pinus sylvestris L.). - Suomen Kemistilehti B 34, 91-92.

Power, D. M., G. H. N. Towers \& A. C. Neish, 1965: Biosynthesis of phenolic acids by certain wood-destroying basidiomycetes. - Can. J. Biochemistry 43, 1397-1407.

Pridham, J. B. ed., 1960: Phenolics in plants in health and disease. - Oxford. $131 \mathrm{pp}$.

Rennerfelt, E. \& G. Nacht, 1955: The fungicidal activity of some constituents from heartwood of conifers. - Svensk Botanisk Tidskrift $49,419-432$.

Robrins, W. J. \& A. Hervey, 1965: Response of eight basidiomycetes to ferulic acid. Bull. Torr. Bot. Club 92, 266-269.

Shain, L., 1967: Resistance of sapwood in stems of loblolly pine to infection by Fomes annosus. - Phytopathology 57, 1.034-1045.

Siegle, H., 1967: Microbiological and biochemical aspects of heartwood stain in Betula papyrifera Marsh. - Can. J. Bot. 45, $147-154$ 